\title{
Comparison of Some Body Measurements of South Anatolian Red and Native Southern Yellow Cattle*
}

\author{
Adnan ÜNALAN \\ Nigde University, Ulukısla Vocation School, Nigde, Turkey
}

Received (Geliş): 10.02 .2016

Accepted (Kabul): 25.03.2016

\begin{abstract}
This study was conducted with the aim of determining differences between some body measurements of South Anatolian Red (SAR) and Native Southern Yellow (NSY) cows because of they were generally evaluated in the same cattle breed name in Turkey. In the present study, 92 heads of SAR cows and 100 heads of NSY cows were used as animal material. These cattle types were in in-situ conservation program of domestic animal genetic resource held in 2005. In this context, the herds for SAR and NSY cattle were established in Hatay and Adana provinces, respectively. In the study, four body measurements (Body Length: BL, Withers Height: WH, Rump Height: RH and Chest Depth: CD) of the cattle types were investigated and were compared according to these body measurements. Statistical analysis showed that the overall means $( \pm \mathrm{SE})$ of BL, WH, RH and CD for SAR cows were $141.37 \pm 1.26 \mathrm{~cm}, 123.22 \pm 1.06 \mathrm{~cm}, 128.38 \pm 1.13 \mathrm{~cm}$ and $64.06 \pm 0.53 \mathrm{~cm}$ respectively. The overall means of body measurements indicated above for NSY cows were $119.29 \pm 0.84 \mathrm{~cm}, 103.29 \pm 0.68 \mathrm{~cm}, 105.70 \pm 0.79 \mathrm{~cm}$ and $55.63 \pm 0.39 \mathrm{~cm}$ respectively. Independent two-sample t-test showed that the mean differences all of body measurements between two cattle types were statistically significant $(\mathrm{P}<0.01)$. The results supported that these cattle types were different cattle breeds, although they were generally evaluated in the same cattle breed name (as Native Yellow Red cattle: NYR).
\end{abstract}

Key Words: South Anatolian Red (SAR), Native Southern Yellow (NSY), Body Measurements, Genetic Resource, Conservation

\section{Güney Anadolu Kırmızısı ve Yerli Güney Sarısı Sığırların Bazı Vücut Özelliklerinin Karşılaştırması}

ÖZET: Bu çalışma, ülkemizde genellikle aynı isim altında değerlendirilen Güney Anadolu Kırmızısı (GAK) ve Yerli Güney Sarısı (YGS) sığırların bazı vücut ölçüleri arasındaki farklılıkların belirlenmesi amacıyla yürütülmüştür. Çalışmada, hayvan materyali olarak yerli hayvan genetik kaynakların yerinde (çiftçi şartlarında) korunması amacıyla 2005 yılında GAK sığırlar için Hatay ilinde oluşturulmuş sürüdeki 92 baş inek ile YGS sığırlar için Adana ilinde oluşturulmuş sürüdeki 100 baş inek kullanılmıştır. Çalışmada, bu sığırlara ait dört farklı vücut ölçüsü (Vücut Uzunluğu: VU, Cidago Yüksekliği: CY, Sağrı Yüksekliği: SY ve Göğüs Derinliği: GD) kullanılmış ve bu özellikler yönünden sığırlar karşılaştırmalı olarak incelenmiş̧tir. İstatistik analizler sonunda, GAK ineklerde vücut uzunluğu, cidago yüksekliği, sağrı yüksekliği ve göğüs derinliği genel ortalamaları $( \pm \mathrm{SH})$ sırasıyla $141.37 \pm 1.26 \mathrm{~cm}, 123.22 \pm 1.06 \mathrm{~cm}, 128.38 \pm 1.13 \mathrm{~cm}$ ve $64.06 \pm 0.53 \mathrm{~cm}$ olarak bulunurken, YGS ineklerde bu özellikler için genel ortalamalar sırasıyla $119.29 \pm 0.84 \mathrm{~cm}, 103.29 \pm 0.68 \mathrm{~cm}, 105.70 \pm 0.79 \mathrm{~cm}$ ve $55.63 \pm 0.39 \mathrm{~cm}$ olarak bulunmuştur. Bağımsız iki örneklem t-testi, incelenen bu özellikler bakımından bu sığır tipleri arasında istatistiksel olarak önemli fark olduğunu göstermiştir $(\mathrm{P}<0.01)$. Çalışmadan elde edilen bu sonuçlar, genellikle aynı ırk adı altında (Güney Sarı Kırmızı: GSK) değerlendirilen bu sığırların iki farklı ırk olduğunu destekler nitelikte bulunmuștur.

Anahtar Kelimeler: Güney Anadolu Kırmızısı (GAK), Yerli Güney Sarısı (YGS), Vücut Ölçüleri, Genetik Kaynak, Koruma

\section{INTRODUCTION}

Today, it is informed that there are totally 897 cattle breeds on worldwide, Turkey has also 23 native cattle breeds (called as groups or types), but 15 breeds of them were nonexistence in the last 50 years, 6 breeds of them have already been under the risk, only 2 breeds (East Anatolian Red and Native Black) are widely reared in Turkey (Soysal, 2010).

It is well known that dairy cattle farmers prefer high yielded exotic cattle breeds (i.e. Holstein) in Turkey (Unalan, 2009). However, some problems (management, nutrition and production etc.) related to keeping of this breed in non-intensive farming systems, especially in high and mountainous regions may be occurred. Therefore, the other cattle breeds, especially native breeds are preferred by the farmers in the different region of Turkey (Ünalan and Çankaya, 2010). In this case, conservation of native livestock breeds (cattle, sheep, goat etc.) is becoming increasingly important day to day.

In general, Turkey has large animal genetic resources in terms of natural life and has also livestock genetic resources. However, our native animal genetic resources are now faced to nonexistence risk because of

This study was presented orally in the International Animal Science Congress of Turkish and Relatives Communities held in 11-13 September 2012 in Suleyman Demirel University, Isparta, Turkey.

Corresponding author: Ünalan, A., unalanadnan@ gmail.com 
uncontrolled and unconscious cross-breeding with the exotic breeds (Ünalan, 2007a).

South Anatolian Red (SAR) and Native Southern Yellow (NSY) cattle are widely reared in the southern region of Turkey and these native cattle types are now just becoming as an important genetic resource for that region. Of course, it is firstly needed to determine these genetic resources correctly and to describe the breed's characteristics of these cattle types. Many studies have been conducted on these cattle types up today. But, in general, these cattle types were combined or evaluated in the same breed's name as "Native Yellow Red" or "Kilis type" cattle in many previous studies (Özcan et al., 1976a; Özcan et al., 1976b; Karakaş, 1980; Şekerden and Pekel, 1982; Şekerden and Özkütük, 1990; Cebeci et al., 1993; Pekel et al., 1993). Especially, there was not enough number of studies on South Anatolian Red (SAR) cattle and Native Southern Yellow (NSY) cattle are the same or different breeds until 2005. But, it was reported that these two cattle types were different cattle breeds in a PhD Thesis made in 2005 (Altınalan, 2005).

The first and most comprehensive study in order to determine cattle breed's characteristics reared in South Anatolian region of Turkey was conducted in 1956 (Eker, 1956). In this study, it was reported two cattle types called as "Native South Anatolian Red (SAR)" cattle usually reared in lowlands and had quite high milk yielded and had large bodies, and called as "Native
Southern Yellow (NSY)" cattle abundantly reared higher and rough regions and had small body size. Consequently, it was also reported that these cattle types (SAR and NSY) would might be different cattle breeds by this researcher. Unfortunately, this study was the first and only research conducted on NSY cattle. Although many researches were carried out to determine some features of SAR cattle (Cankaya et al., 2005; Ünalan and Ișık, 2007; Öztabak et al., 2010), there was no study for NSY cattle type. This situation was shown that in the searching literature on these cattle types as being registration of different cattle breeds (as SAR and NSY Turkish native cattle breeds) in 2004 (in the terms of Notification of Native Animal Breeds and Lines Registration on 12 December, 2004 dated and 25668 numbered of the Turkish Official Gazette) (Resmi Gazete, 2004).

Literature about some body measurements of both cattle types were summarized in Table 1.

Consequently, although SAR and NSY cattle types were registered as two different Turkish native cattle breed in 2004, only one research results (Eker, 1956) were used for the registration of NSY cattle not to be the same breed with SAR cattle. For this reason, this study was conducted to investigate comparatively some body measurements of these cattle types commonly reared by the cattle breeders in southern regions of Turkey, and to contribute mainly literature about NSY cattle.

Table 1. Literature for some body measurements of SAR and NSY cattle

\begin{tabular}{lccccc}
\hline Cattle Breeds & $\mathrm{n}$ & $\mathrm{BL}$ & MH & RH & CD \\
\hline SAR & 21 & 144.4 & 139 & - & 68.1 \\
$\quad$ Bilgemre (1952) & 22 & - & 137 & - & - \\
Batu (1956) & 217 & 139.2 & 128.9 & 134.3 & 62.1 \\
$\quad$ Eker (1956) & 29 & 148.3 & 137.6 & 140.3 & 67.5 \\
$\quad$ Pekel et al. (1993) & \multicolumn{5}{l}{} \\
NSY & 146 & 111.6 & 107.0 & 112.6 & 54.6 \\
$\quad$ Eker (1956) & \multicolumn{7}{l}{} \\
\hline SAR: South Anatolian Red, NSY: Native Southern Yellow \\
BL: Body Length, WH: Withers Height, RH: Rump Height, CD: Chest Depth
\end{tabular}

\section{MATERIAL and METHODS}

In this study, 92 heads of South Anatolian Red (SAR) cows and 100 heads of Native Southern Yellow (NSY) cows were used as animal material. The 26, 22, 19,14 and 11 heads of SAR cows and 28, 24, 20, 15 and 13 heads of NSY cows were 3, 4, 5, 6 and 7 years of age respectively. The means age of SAR and NSY cows were 4.59 and 4.61 years respectively. SAR cows were selected among 127 animals belonged to 23 cattle breeders in the conservation herd in Güzelce village of Kirıkhan distinct of Hatay. NSY cows were selected among 147 animals belonged to 61 cattle breeders in the conservation herd in Süphandere and Bağdatlı villages of Feke distinct of Adana in terms of in-situ conservation of domestic animals genetic resources (Resmi Gazete, 2005; Ünalan, 2007b) by held in
General Directorate of Agricultural Researches of the Ministry of Agriculture and Rural Affairs, and directed by Adana Çukurova Agricultural Research Institute in 2005. In the present study, four body measurements (Body Length: BL, Withers Height: WH, Rump Height: RH and Chest Depth: CD) of these cattle types were used and were compared according to these body measurements.

Because control difficulty of the native cattle breeds, especially NSY cattle being primitive and their regional and geographical hardships, to obtain the body measurements of cows; firstly, all cows were marked by dimension of $10 \times 10 \mathrm{~cm}$ reference tag and then photos of cows were taken (Figure 1 and Figure 2) and finally the body measurements of cows were computed from the 
photos by processing in Image Pro-Plus 4.5 Software (Figure 3).

Body measurements of two cattle types were analyzed by independent two-sample t-test for each age group and the overall means according to statistical model given below in SPSS 12.0 Program.

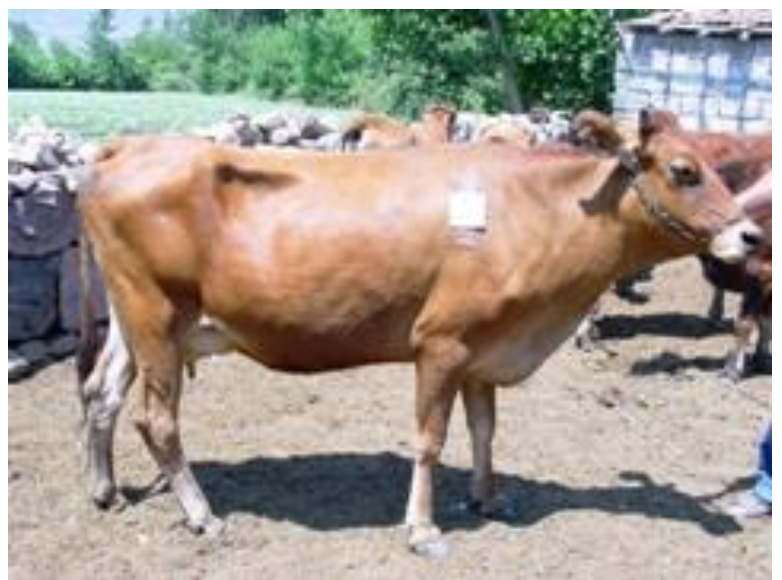

Figure 1. A photo of South Anatolian Red (SAR) cow

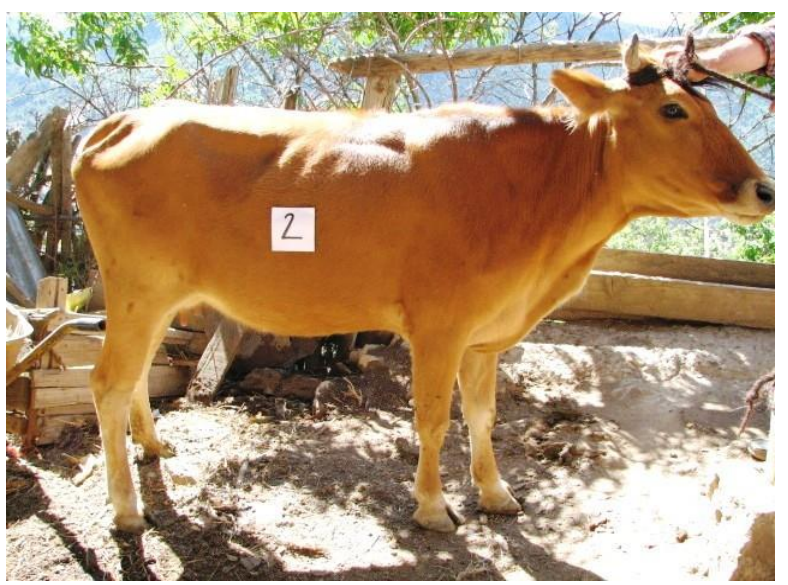

Figure 2. A photo of Native Southern Yellow (NSY) cow

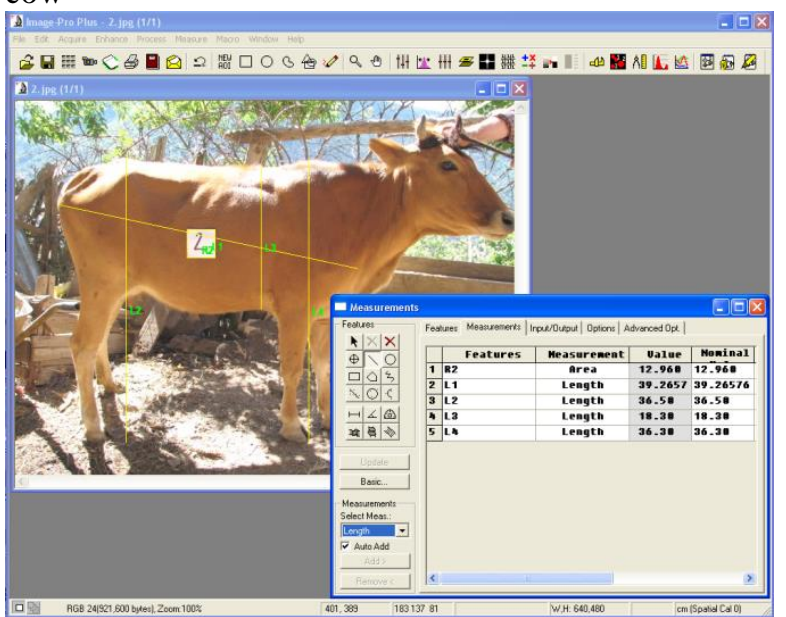

Figure 3. A screenshot computing of cows' body measurements by Image Pro-Plus 4.5 Software
Cattle types were assumed as fixed effect in the analysis. Besides, phenotypic correlations among the body measurements for each cattle type were also estimated.

$$
\mathrm{Y}_{t i j}=\mu_{t}+\mathrm{c}_{t i}+\mathrm{e}_{t i j}
$$

In the equation:

$\mathrm{Y}_{t i j}: \mathrm{t}^{\text {th }}$ measurement value of $\mathrm{j}^{\text {th }}$ cow in $\mathrm{i}^{\text {th }}$ cattle type $(\mathrm{t}=1$ : body length, 2 : withers height, 3 : rump height ve 4: chest depth), $\mu_{t}$ : general mean of $\mathrm{t}^{\text {th }}$ measurement, $\mathrm{c}_{t i \text { : }}$ $\mathrm{i}^{\text {th }}$ cattle type effect for $\mathrm{t}^{\text {th }}$ measurement $(\mathrm{i}=1,2), \mathrm{e}_{t i j}$ : random error for $\mathrm{t}^{\text {th }}$ measurement.

\section{RESULTS}

The least square means $( \pm \mathrm{SE})$ of body measurements of the cattle types and independent two-sample t-test results for each age group and overall means were given in Table 2 .

As seen in Table 2, the mean differences of body measurements between two cattle types both each age group and the overall means were statistically significant $(\mathrm{P}<0.01)$. For all investigated body measurements SAR cows had higher overall means than NSY cows. SAR cows had higher means about $22 \mathrm{~cm}$ (\%18.5), $20 \mathrm{~cm}(\% 19.4), 23 \mathrm{~cm}(\% 21.5)$ and $8 \mathrm{~cm}$ (\%15.2) for body length, withers height, rump height and chest depth, respectively than the overall means of NSY cows.

One of the breed's characteristics of SAR cows is tail binding point and depending on this feature, rump is higher than withers (Ünalan, 2007a). In the present study, rump height of SAR cows was found higher about $5 \mathrm{~cm}$ than withers. This result was in accordance with the previously reported results.

In general, all results obtained from this study were nearly similar to the previously reported results, especially with the results of by Eker (1956).

Correlations among the body measurements of two cattle types were given in Table 3 .

As seen in Table 3, the phenotypic correlations among the body measurements for each cattle type were highly positive and statistically significant $(\mathrm{P}<0.01)$. However, phenotypic correlations among the body measurements of SAR cows were also higher $(39.3 \%, 30.0 \%, 16.6 \%, 2.5 \%, 15.1 \%$ and $16.7 \%$ for $\mathrm{BL}$ and $\mathrm{WH}, \mathrm{BL}$ and $\mathrm{RH}, \mathrm{BL}$ and $\mathrm{CD}, \mathrm{WH}$ and $\mathrm{RH}, \mathrm{WH}$ and $\mathrm{CD}$, and $\mathrm{RH}$ and $\mathrm{CD}$, respectively) than the correlations of NSY cows. In addition, the highest phenotypic correlations were found to be between WH and RH as 0.900 and 0.878 for SAR and NSY cows respectively, the lowest phenotypic correlations were found to be between $\mathrm{BL}$ and $\mathrm{RH}$ as 0.787 and 0.605 for SAR and NSY cows respectively. 
Table 2. The least square means $( \pm$ SE) of the body measurements of cows and t-test results

\begin{tabular}{|c|c|c|c|c|c|}
\hline \multirow{2}{*}{ Breeds/Ages } & \multicolumn{5}{|c|}{ Body Measurements } \\
\hline & $\mathrm{n}$ & BL & WH & RH & $\mathrm{CD}$ \\
\hline \multicolumn{6}{|l|}{3 years of age } \\
\hline SAR & 26 & $127.55 \pm 1.57^{\mathrm{a}}$ & $112.70 \pm 1.43^{\mathrm{a}}$ & $117.61 \pm 1.41^{\mathrm{a}}$ & $58.51 \pm 0.66^{\mathrm{a}}$ \\
\hline NSY & 28 & $110.42 \pm 0.47^{\mathrm{b}}$ & $98.60 \pm 1.22^{\mathrm{b}}$ & $100.47 \pm 1.30^{\mathrm{b}}$ & $52.48 \pm 0.47^{\mathrm{b}}$ \\
\hline \multicolumn{6}{|l|}{4 years of age } \\
\hline SAR & 22 & $138.39 \pm 0.68^{\mathrm{a}}$ & $121.81 \pm 0.91^{\mathrm{a}}$ & $126.82 \pm 1.47^{\mathrm{a}}$ & $62.61 \pm 0.43^{\mathrm{a}}$ \\
\hline NSY & 24 & $115.74 \pm 0.47^{\mathrm{b}}$ & $101.85 \pm 1.18^{b}$ & $103.88 \pm 1.37^{\mathrm{b}}$ & $54.83 \pm 0.50^{\mathrm{b}}$ \\
\hline \multicolumn{6}{|l|}{5 years of age } \\
\hline SAR & 19 & $145.73 \pm 0.76^{\mathrm{a}}$ & $126.45 \pm 1.41^{\mathrm{a}}$ & $130.80 \pm 1.42^{\mathrm{a}}$ & $66.32 \pm 0.70^{\mathrm{a}}$ \\
\hline NSY & 20 & $121.59 \pm 0.57^{\mathrm{b}}$ & $105.00 \pm 1.00^{\mathrm{b}}$ & $106.52 \pm 0.86^{\mathrm{b}}$ & $56.18 \pm 0.72^{\mathrm{b}}$ \\
\hline \multicolumn{6}{|l|}{6 years of age } \\
\hline SAR & 14 & $152.03 \pm 0.69^{\mathrm{a}}$ & $130.56 \pm 1.28^{\mathrm{a}}$ & $136.13 \pm 1.60^{\mathrm{a}}$ & $68.23 \pm 0.65^{\mathrm{a}}$ \\
\hline NSY & 15 & $125.80 \pm 0.42^{\mathrm{b}}$ & $105.53 \pm 1.48^{\mathrm{b}}$ & $109.67 \pm 1.90^{\mathrm{b}}$ & $57.93 \pm 0.61^{\mathrm{b}}$ \\
\hline \multicolumn{6}{|l|}{7 years of age } \\
\hline SAR & 11 & $159.66 \pm 1.58^{\mathrm{a}}$ & $138.04 \pm 1.75^{\mathrm{a}}$ & $142.93 \pm 2.84^{\mathrm{a}}$ & $70.93 \pm 0.75^{\mathrm{a}}$ \\
\hline NSY & 13 & $133.88 \pm 1.72^{\mathrm{b}}$ & $110.82 \pm 1.51^{b}$ & $114.53 \pm 2.15^{\mathrm{b}}$ & $60.43 \pm 1.18^{b}$ \\
\hline \multicolumn{6}{|l|}{ Overall } \\
\hline SAR & 92 & $141.37 \pm 1.26^{\mathrm{a}}$ & $123.22 \pm 1.06^{\mathrm{a}}$ & $128.38 \pm 1.13^{\mathrm{a}}$ & $64.06 \pm 0.53^{\mathrm{a}}$ \\
\hline NSY & 100 & $119.29 \pm 0.84^{b}$ & $103.29 \pm 0.68^{b}$ & $105.70 \pm 0.79^{b}$ & $55.63 \pm 0.39^{b}$ \\
\hline
\end{tabular}

SAR: South Anatolian Red, NSY: Native Southern Yellow

BL: Body Length, WH: Withers Height, RH: Rump Height, CD: Chest Depth

${ }^{a, b}$ Different letters in the same column indicate statistically significant differences ( $t$-test, $\left.\mathrm{P}<0.01\right)$

Table 3. Phenotypic correlations among the body measurements of the cattle types

\begin{tabular}{ccccc}
\hline Measurements & BL & WH & RH & CD \\
BL & & $0.861 * *$ & $0.787 * *$ & $0.892^{* *}$ \\
WH & $0.618^{* *}$ & & $0.900^{* *}$ & $0.875^{* *}$ \\
RH & $0.605^{* *}$ & $0.878^{* *}$ & & $0.788^{* *}$ \\
CD & $0.765^{* *}$ & $0.760 * *$ & $0.675^{* *}$ & \\
\hline
\end{tabular}

BL: Body Length, WH: Withers Height, RH: Rump Height, CD Chest Depth

Phenotypic correlation coefficients: above diagonal for SAR cattle, below diagonal for NSY cattle, $* * \mathrm{P}<0.01$

\section{DISCUSSION}

Both statistically significant mean differences of the body measurements between SAR and NSY cows and different phenotypic correlations among the body measurements in each cattle type supported that these cattle types were not the same cattle breed. Phenotypic correlations among the body measurements of SAR cows were higher (ranged from $2.5 \%$ to $39.3 \%$ ) than the correlations of NSY cows. In addition, it is well known that NSY cows have smaller body size than SAR cows. Although NSY cows have low milk yield, this cattle breed is commonly reared in high mountainous, rough and insufficient food source region of Turkey because of their smaller body size and weight. Consequently, determination of morphological differences of these cattle breeds and conservation of both NSY and SAR cattle breeds are very important to maintain indigenous animal genetic diversity and sustainable cattle breeding in Turkey.

\section{REFERENCES}

Altınalan, A. 2005. Türkiye'deki Yerli Sığır Irklarının Mikrosatellit DNA Markırlarla Genetik Karakterizasyonu. Ç.Ü. Fen Bil. Ens., Zootekni ABD, Doktora Tezi, Adana.

Batu, S. 1956. Dünya Sığır Irkları. Ankara Üniversitesi Veteriner Fakültesi Yayınları: 78, Ders Kitabı: 33, Ankara. (Çeviri: S. Batu, Yazar: Dr. A. Schmid).

Bilgemre, K. 1952. Özel Zootekni I Sığır Yetiştirmek (2. Bask1). Ankara Üniversitesi Ziraat Fakültesi Yayınları: 35, Ders Kitabı: 16, Ankara.

Cankaya, S., Kayaalp, G.T., Unalan, A., 2005. Estimation of correlation among sex, birth weight and some body measurements in South Anatolian Red calves by using canonical correlation analysis. $3^{\text {rd }}$ International Conference of the EMR-IBS, May 9-12 2005, Corfu, Greece.

Cebeci, Z., Özkütük, K., Pekel, E. 1993. Ceylanpınar Tarım İşletmesi koşullarında yüksek çevre sıcaklığının Kilis ve Siyah Alaca sığırlarının bazı fizyolojik karakterleri üzerine etkisi. Güneydoğu Anadolu 1. Hayvancilık Kongresi, 12-15 Mayıs, Şanliurfa.

Eker, M. 1956. Güney Anadolu Sı̆̆ır Yetiştiriciliği Sı̆̆ır Irkları ve Bunların Morfolojik Irk Iraları, Ankara Üniversitesi Ziraat Fakültesi Yayınları: 85 Çalışmalar: 46, Ankara.

Karakaş, S. 1980. Siyah Alaca, Kilis tipi Güney Sarı Kırmızı inekler ile bunların çeşitli kan dereceli melezlerinde süt verimi ve laktasyon süreleri üzerinde bir araştırma. Çukurova Üniversitesi Ziraat Fakültesi Hayvan Yetiştirme ve Islahı Bölümü, Adana. 
Özcan, L., Pekel, E., Uluocak, N., Şekerden, Ö. 1976a Çukurova Bölgesinde yetiştirilen Kilis sığırlarının 1slahında Holstein Friesian genotipinden yararlanma olanakları I. gelișimle ilgili özellikler. Cukurova Üniversitesi Ziraat Fakültesi Yıllığı, Ayrı Baskı, Y1l: 7, Sayı: 1, Adana.

Özcan, L., Pekel, E., Şekerden, Ö., Uluocak, N. 1976b. Çukurova Bölgesinde yetiştirilen Kilis tipi Güney Kırmızı sığırların 1slahında Siyah Alaca genotipinden yararlanma olanakları. II. döl ve süt verimleri ile ilgili özellikler. Çukurova Üniversitesi Ziraat Fakültesi Yıllığı, Ayrı Baskı, Yı1: 7, Sayı: 2, Adana.

Öztabak, K., Toker, N.Y., Ün, C., Akış, I., Mengi, A., Karadağ, O., Soysal, D., 2010. Leptin gene polymorphism in native Turkish cattle breeds. Journal of the Faculty of Veterinary Medicine, Kafkas University, 16(6):921-924.

Pekel, E., Özkütük, K., Cebeci, Z., Kumlu, S., Öztürkcan, O., Görgülü, M. 1993. Kilis tipi Güney Sarı Kırmızı sığırların yayılış alanı, performansları ve GAP Bölgesi için bu sığırlardan yararlanma olanakları. Ç.Ü. Ziraat Fakültesi Güneydoğu Anadolu Projesi (GAP) Tarımsal Araştırma İnceleme ve Geliştirme Proje Paketi, Proje Sonuç Raporu. Çukurova Üniversitesi Ziraat Fakültesi Genel Yayın No: 64, GAP Yayınları No: 75, Adana.

Resmi Gazete, 2004. 12 Aralık 2004 Tarih ve 25668 Sayılı Resmi Gazete. Yerli Hayvan Irk ve Hatlarının Tescili Hakkında Tebliğ.

Resmi Gazete, 2005. 24 Mart 2005 Tarih ve 25765 Sayılı Resmi Gazete. Hayvancılığın Desteklenmesi Hakkında Bakanlar Kurulu Kararının 2005/13 No'lu Uygulama Tebliği.

Soysal, M.I. 2009. Evcil hayvan genetik kaynakları çeşitliliği tehdit altında. http://site.mynet.com/genkaynaklari/Hazirlar/gen_ka ynaklari_korunmali.htm (Access date: 21.03.2012)
Şekerden, Ö., Pekel, E. 1982. Reyhanlı Devlet Üretme Çiftliğinde yetiştirilen saf Siyah Alaca, Kilis tipi Güney Kırmızı sığırlar ve bunların melezlerinin döl ve süt verim özellikleri ile bazı parametrelerin tahmini üzerine bir araştırma. Çukurova Üniversitesi Ziraat Fakültesi Yıllığı Ayrı Baskı Yı1:13, Sayı:3-4, Adana.

Şekerden, Ö., Özkütük, K. 1990. Büyükbaş Hayvan Yetiștirme. Çukurova Üniversitesi Ziraat Fakültesi Ders Kitabi: 122, Adana.

Unalan, A. 2009. Estimation of genetic parameters and correlations among some body measurements of Holstein calves and effects of these measurements on calving difficulty. Journal of Animal and Veterinary Advances, 8 (8):1589-1594.

Ünalan, A. 2007a. Gen kaynaklarını koruma projesi (Kilis sığırı: Güney Anadolu Kırmızısı). http://www.tarim.gov.tr/Files/Files/e_kutuphane/gkk p_kilis_sigiri.pdf (Access date: 21.03.2012).

Ünalan, A. 2007b. Gen kaynaklarının halk elinde korunması projesi (Kilis sı̆̆ır, Yerli Güney Sarısı sığırı, Kilis keçisi). http://www.tagem.gov.tr/yayin/ gkhek.pdf (Access date: 21.03.2012).

Ünalan, A., Işık, A. 2007. A Study on determination of environmental effects and phenotypic correlations among some body measurements of South Anatolian Red (Kilis) calves. Journal of the Faculty of Agriculture, Çukurova University, 22 (2):1-6.

Ünalan A., Çankaya, S. 2010. Genetic parameters and correlations for lactation milk yields according to lactation number in Jersey cows. Journal of the Faculty of Veterinary Medicine, Kafkas University, 16 (6):995-1000. 